\title{
Effect of Body Condition Score and PCR-RFLP Polymorphism of Prolactin Gene on Semen Characteristics of Buffalo Bulls (BubalusBubalis)
}

\author{
M.H. Hasanain*, Karima Gh.M. Mahmoud*, Y.F. Ahmed ${ }^{*}$ A.A. EL-Menoufy ${ }^{* *}$, \\ A.M. Sakr ${ }^{* * *}$, and Othman. E. Othman ${ }^{* * * *}$ \\ ${ }^{*}$ Department of Animal Reproduction and A.I., National Research Centre ${ }^{* *}$ Department \\ of Theriogenology, Faculty of Veterinary Medicine, Cairo University ${ }^{* * *}$ Department of \\ Biotechnology, Animal Production Research Institute and ${ }^{* * * *}$ Cell Biology Department, \\ National Research Centre, Cairo, Egypt.
}

\begin{abstract}
$\mathbf{T}$ HIS WORK aimed to evaluate effect of body condition score on semen characteristics of buffalo bulls and identify the genetic polymorphisms of prolactin (PRL) gene as bases for selection of bulls with good breeding value.The study was performed on 60 buffalo bulls aged 2-8 years. The bulls were classified according to body condition score (BCS) into two groups. The first group of bulls was between 2 to $<3$ scores (n 33), while the second group was between 3 to $<4$ scores (n 27). Three semen collections were obtained from each animal at 15-day intervals and evaluated for volume, individual motility, live sperm $\%$ and chromatin integrity. DNA was extracted from semen for genotyping of PRL gene Xbal locus of regulatory region using PCR-RFLP technique. The results showed that, body condition score had no significant effect on semen characteristics. XbaI PCR-RFLP of PRL gene showed genetic polymorphism in 678 bp PCR fragment including two genotypes AA and BB.The genotype AA (678 bp) had high frequencies (91.67\%) while the genotype BB (231 and $447 \mathrm{bp}$ ) had low frequencies $(8.33 \%)$. There were no association between the two genotypes of prolactin gene and the studied semen parameters. It could be concluded that, BCS of buffalo bulls had no effect on semen quality. The presence of genetic polymorphism in prolactin $\mathrm{XbaI}$ locus of buffalo bulls may acts as a genetic marker using large number of animals.
\end{abstract}

Key words: Buffalo, Semen, PRL gene, PCR, RFLP.

\section{Introduction}

Semen evaluation is of high diagnostic importance for assessing testicular and epididymal function, and/or the male genital tract to eliminate the prominent cases of infertility, or potential subfertility [1,2],thereby the main goal of semen evaluation is to predict its fertilizing and cryopreservation ability for artificial insemination to obtain acceptable pregnancy rates $[3,4]$. Recently AI became a tool of disseminating superior genes for economic traits like milk production [5-7]. Sperm DNA integrity may be a good marker for measurement of male fertility potential [8,9]. Rasul et al. [10] reported that, freezing and thawing of buffalo semen may cause a considerable damage to DNA, acrosomal cap, plasma membrane, and motility apparatus, hence evaluation of DNA integrity is important in the design of new freezing-thawing steps
There are several hormones that regulate lactation and reproduction in bovines. One of them is prolactin, which is a polypeptide hormone synthesized and secreted from primarily the lactotrophes of the anterior pituitary gland in bovines and other vertebrates [11]. PRL gene is expressed in the pituitary gland, and at several other sites including the mammary gland, the central nervous system and the immune system $[12,13]$, that allows PRL to have multiple biological functions related to reproduction, osmoregulation, integument growth and synergism with steroids [14]. Additionally, Lazebnaya et al. [15] concluded that, the binding of the bPRL gene product,after its expression, with its receptor initiates a signaling cascade that activates the transcription of a number of genes, including the genes of milk proteins (caseins and lactalbumin). 
It was reported that, bovine prolactin gene (bPRL) is located on chromosome 23 in the bovine genome $[14,16]$. The bPRL gene size is about $10 \mathrm{~kb}$ and consists of five exons and four introns [17], that encodes 199 amino acids mature protein [18]. The bPRL gene is considered as a common candidate gene for marker-assisted selection for milk production parameters [19].The polymorphisms of prolactin gene and its relationship with milk related traits were confirmed in various cattle breeds [20-26]. However, few studies were done on genotyping this hormone in buffalo [27-29]. It was shown that polymorphism in the structural or regulatory sequences of the PRL gene would be significant to study due to its possible direct and indirect role on milk production traits [29]. So this study aimed to evaluate effect of body condition score on semen characteristics and to identify the genetic polymorphisms of prolactin gene in buffalo bulls.

\section{Materials and Methods}

\section{Animals}

The study was performed on 60 buffalo bulls (Bubalus bubalis) aged 2-8 years. Buffalo bulls were subjected to semen evaluation and genetic characterization of PRL gene. These bulls belonged to a breeding station at Mahalet Mussa near to Sakha, Kafr el-Sheikh Governorate. All buffalo bulls were subjected to the same management and nutrition programs. The buffalo bulls were classified according to body condition score (BCS) into two groups using a grading scale of 1-5, according to a system for buffalo stated by Alapati et al. [30] where score 1 indicated severe under-condition whereas score 5 indicated severe over-condition (obesity). The first group of bulls was between 2 to $<3$ scores $(n=33)$ while the second group were between 3 to $<4$ scores $(n=27)$.

\section{Semen evaluation}

Volume of the ejaculate was estimated to nearest $0.1 \mathrm{ml}$. Individual motility was expressed as the percentage of forward motile spermatozoa. Live sperm percentage was estimated using eosinnigrosin stained smears. Chromatin integrity was recorded using acridine orange (AO) staining technique $[9,31]$.

\section{DNA extraction from sperm cells}

DNA was extracted from fresh semen according to Weyrich [32] with slight modifications. Fifty $\mu 1$ of semen was washed in $500 \mu \mathrm{l}$ of $70 \%$ ethanol Egypt. J. Vet. Sci.Vol.48, No.1 (2017) then the samples were centrifuged for $5 \mathrm{~min}$ at $10,000 \times \mathrm{g}$ and the supernatant was removed. The former steps were repeated until the supernatant became clear and an easily visible and a white pellet was obtained. About $500 \mu 1$ lysis buffer (50 mMTris-HCl, pH 8; 10 mM EDTA; 100 mMNaCl; $1 \%$ SDS aqueous solution) was added to the sperm pellet. Also, $5 \mu 1$ Triton-X100 (0.5\%), $25 \mu 1$ Dithiothreitol (DTT) $1 \mathrm{M}$ and $50 \mu$ proteinase $\mathrm{K}$ $(20 \mathrm{mg} / \mathrm{ml})$ were added. The samples were mixed well and incubated at $50{ }^{\circ} \mathrm{C}$ overnight in a thermo shaker. The tubes were centrifuged for $10 \mathrm{~min}$ at $15,500 \times \mathrm{g}$ and the supernatant was transferred into a new $1.5 \mathrm{ml}$ tube. Sodium acetate $(\mathrm{NaAc})$ $3 \mathrm{M}$ was added to the supernatant (bout $1 / 10 \mathrm{Vol}$. of the supernatant) and mixed gently. NaAc binds to the DNA and eases the precipitation. An ice cold absolute ethanol was added to the tubes (2 Vol. of the supernatant). DNA was precipitated at $-20^{\circ} \mathrm{C}$ overnight and pelleted by centrifugation for 20 min. at $15,500 \mathrm{x}$ g. The supernatant was carefully removed by pipetting and the white pellet of DNA remained. DNA was washed by dispensing the pellet in $500 \mu 1$ ethanol $(75 \%)$. The samples were centrifuged for $10 \mathrm{~min}$ at $15,500 \mathrm{x} \mathrm{g}$ at room temperature $\left(25-30{ }^{\circ} \mathrm{C}\right)$. The samples were dried until ethanol was evaporated. Avoid drying the pellet completely because it may affect DNA.

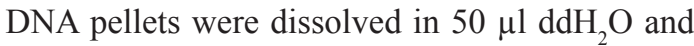
concentration was measured using NanoDrop1000 Thermo Scientific spectrophotometer then diluted to working concentration of $50 \mathrm{ng} / \mu \mathrm{l}$, which is suitable for PCR.

\section{Polymerase Chain Reaction (PCR) and DNA amplification}

The DNA fragment of PRL gene was amplified through polymerase chain reaction technique developed by Mullis et al.[33].The PCR mixture consisted of $12.5 \mu \mathrm{l}$ of PCR master mix (2X) composed of $0.1 \mathrm{U} / \mu \mathrm{l}$ Taq polymerase, $500 \mu \mathrm{M}$ of dNTP each, $20 \mu \mathrm{M}$ of Tris-Hcl (pH 8.3), $100 \mathrm{mM}$ of $\mathrm{Kcl}, 3 \mathrm{mM}$ of $\mathrm{MgCl}$, stabilizer and enhancer. In addition to $1.0 \mu \mathrm{l}$ of forward primer $\mathrm{F}(20 \mathrm{pM} / \mu \mathrm{l}), 1.0 \mu \mathrm{l}$ of reverse primer $\mathrm{R}(20 \mathrm{pM} / \mu \mathrm{l}), 2.0 \mu \mathrm{l}$ of $\mathrm{DNA}(50 \mathrm{ng} / \mu \mathrm{l})$ and add water up to $25 \mu \mathrm{l}$. The sequence of the primers used were F:5' AGGTTAGGAGGATAG-3' and R: 5'TTAGTCAAGTTAGATACCG-3' according to $\mathrm{Li}$ et al. [26] for amplification of $678 \mathrm{bp}$ fragment in 5 'regulation region of PRL gene. PRL gene PCR program for amplification was initial denaturation $95{ }^{\circ} \mathrm{C}$ for $3 \mathrm{~min}$., then 32 cycle of denaturation $95^{\circ} \mathrm{C}$ for $1 \mathrm{~min}$., then an annealing 
at $50.6{ }^{\circ} \mathrm{C}$ for $1 \mathrm{~min}$., then an extension at $72^{\circ} \mathrm{C}$ for $1 \mathrm{~min}$. and a final extension at $72^{\circ} \mathrm{C}$ for $5 \mathrm{~min}$. The PCR reaction products were shown on $2 \%$ agarose gel via electrophoresis and stained with red safe to be visualized on UV transilluminator.

\section{Restriction fragment length polymorphism (RFLP)}

The PCR products for PRL gene were digested with XbaI restriction enzyme. The restriction mixture for each sample was prepared by adding $2.0 \mu \mathrm{l}$ of $10 \times$ restriction buffer to 1.0 $\mu \mathrm{l}$ of $\mathrm{XbaI}$ restriction enzyme and the volume was completed to $20 \mu \mathrm{l}$ by dd $\mathrm{H}_{2} \mathrm{O}$ then mixed with $10 \mu \mathrm{l}$ PCR product. Fast digest restriction enzyme was used. This restriction mixture was incubated at $37^{\circ} \mathrm{C}$ for $25 \mathrm{~min}$. The digested PCR products were showed on $2 \%$ agarose gel by electrophoresis and stained with red safe to be visualized on UV transilluminator.

\section{Statistical analysis}

The obtained data were expressed as mean \pm SE.The effect of body condition score and genotypes of prolactin gene on the studied semen parameters were analyzed by $t$-test using SPSS version 16 software. The differences were considered to be significant at $\mathrm{P}<0.05$.

\section{Results}

Semen evaluation

Data in Table 1 showed a non-significant effect of body condition score on fresh semen characteristics of buffalo bulls except for live sperm percentage. The averages of ejaculate volume $(\mathrm{ml})$, individual motility percentage, live sperm percentage and sperm cells with chromatin damages were $2.76 \pm 0.17,78.26 \pm 0.85$, $82.16 \pm 0.68$ and $0.70 \pm 0.13$ respectively in bulls with body condition score between 2 to $<3$. Meanwhile, the corresponding values for the bulls with body condition score between 3 to $<4$ were $2.61 \pm 0.07,78.10 \pm 0.87,80.30 \pm 0.60$ and $0.86 \pm 0.14$ respectively.

TABLE 1. Effect of body condition score on fresh semen characteristics of buffalo bulls (Mean \pm SE).

\begin{tabular}{lcccc}
\hline Body condition score & $\begin{array}{c}\text { Ejaculate } \\
\text { volume } \\
(\mathbf{m l})\end{array}$ & $\begin{array}{c}\text { Individual } \\
\text { Motility \% }\end{array}$ & Live sperm \% & $\begin{array}{c}\text { Chromatin } \\
\text { damage \% }\end{array}$ \\
\hline 2 to $<3$ (33 animal) & $2.76 \pm 0.17$ & $78.26 \pm 0.85$ & $82.16 \pm 0.68^{*}$ & $0.70 \pm 0.13$ \\
3 to $<4$ (27 animal) & $2.61 \pm 0.07$ & $78.10 \pm 0.87$ & $80.30 \pm 0.60$ & $0.86 \pm 0.14$ \\
\hline
\end{tabular}

${ }^{*} \mathrm{p}<0.05$ (t-Test).

\section{Genotyping of Prolactin (PRL) gene}

A total number of 60 buffalo bulls were tested for polymorphism in PRL gene using PCR-RFLP technique. All the tested buffalo bulls gave PCR specific band at the expected size 678 bp from 5 regulatory region of PRL gene (Fig. 3).

By using RFLP technique, these PCR amplified fragments of 678-bp were digested with XbaI restriction endonuclease depending on the presence or absence of the restriction site at position $231^{\wedge} 447$ and gave two patterns of genotypes AA and BB. Pattern AA is the amplified PCR product of $678 \mathrm{bp}$ from buffalo remained undigested by XbaI restriction enzyme while pattern BB when the amplified PCR product of $678 \mathrm{bp}$ digested by $\mathrm{XbaI}$ restriction enzyme into two fragments 231 and 447 bp (Fig. 4).

Results displayed the presence of AA genotype in high frequencies $(91.67 \%)$ where 55 animals from 60 were AA while BB genotype recorded low frequencies $(8.33 \%)$ where only 5 animals from 60 were genotyped as BB (Table 2). Hence, the allele frequencies also indicated more prominent allele A and less prominent allele B in the studied bulls. These results showed a polymorphic pattern of that fragment of this gene with presence of genetic variation in Egyptian buffalo bulls studied population.

Regarding the effect of genotypes of prolactin gene $(\mathrm{AA}$ and $\mathrm{BB})$ on characteristics of buffalo semen, the ejaculate volume $(\mathrm{ml})$, individual motility $\%$, live sperm $\%$ and chromatin damage $\%$ were $2.45 \pm 0.11$ and $2.90 \pm 0.35 \mathrm{ml}, 75.40 \pm 1.48$ and $76.80 \pm 2.14,81.50 \pm 1.55$ and $79.80 \pm 1.42$ and $0.85 \pm 0.37$ and $1.30 \pm 0.47$ for the genotype AA and genotype BB respectively (Table, 3).Statistical analysis revealed no significant differences in all parameters studied between the two genotypes of prolactin gene. 


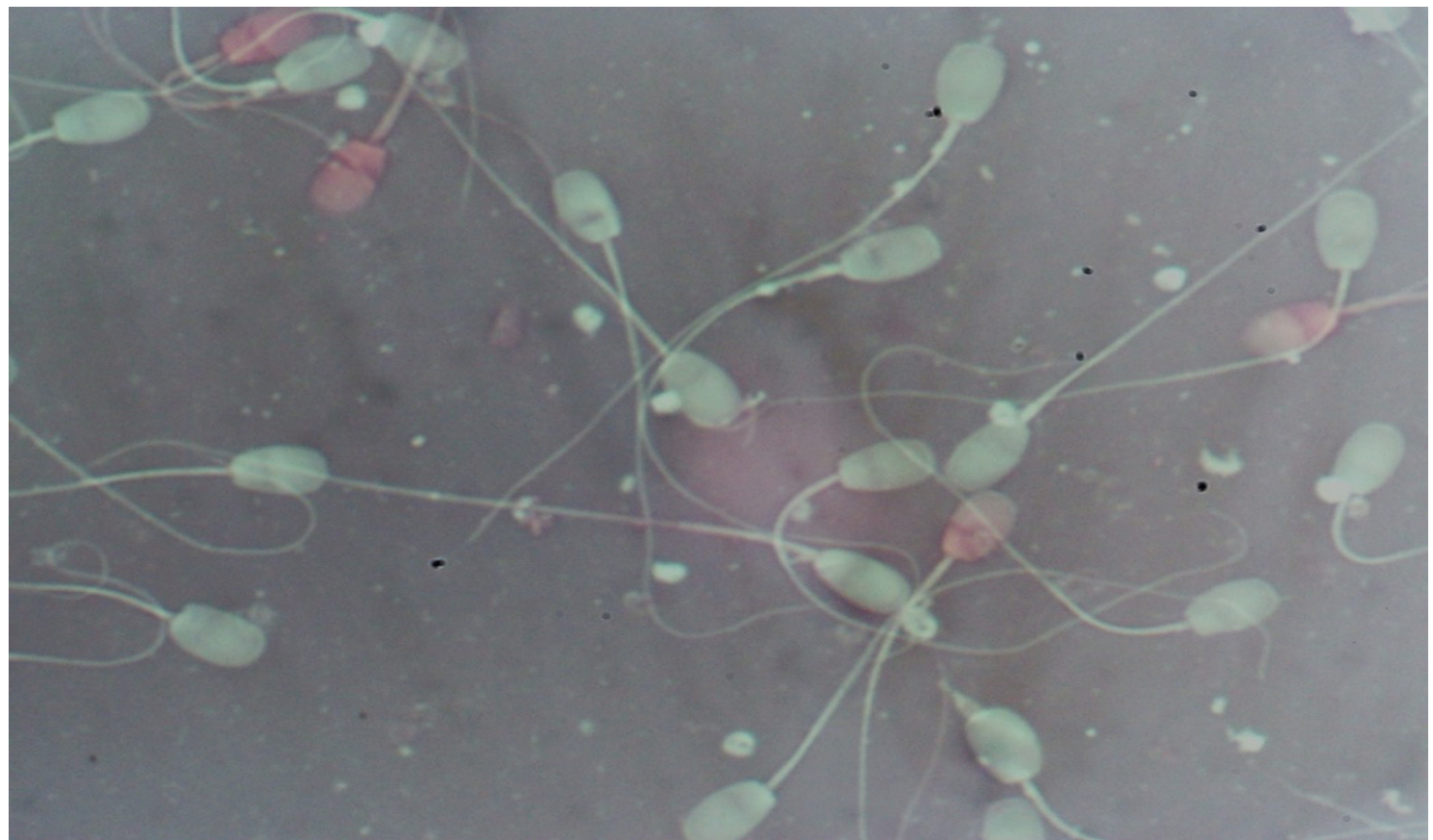

Fig.1. Light microscopy for buffalo spermatozoa stained by eosin-nigrosin stain, live sperm appeared white and dead sperm appeared pink or red color of eosin (x1000).

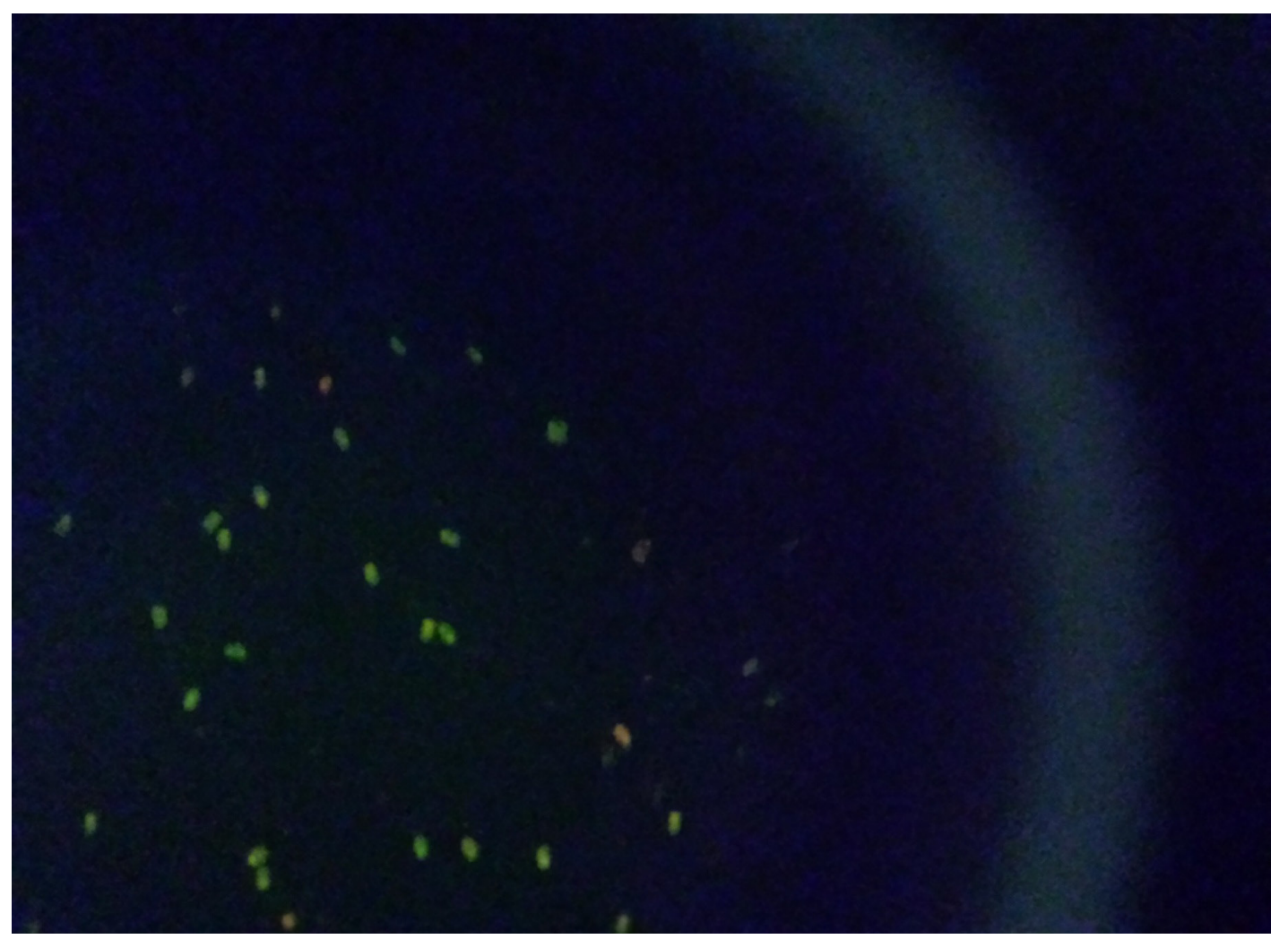

Fig.2 . Fluorescence microscopy for buffalo spermatozoa stained by acridine orange stain, damaged chromatin appeared yellow or red color of acridine orange stain and normal chromatin appeared green color $(\times 400)$. 


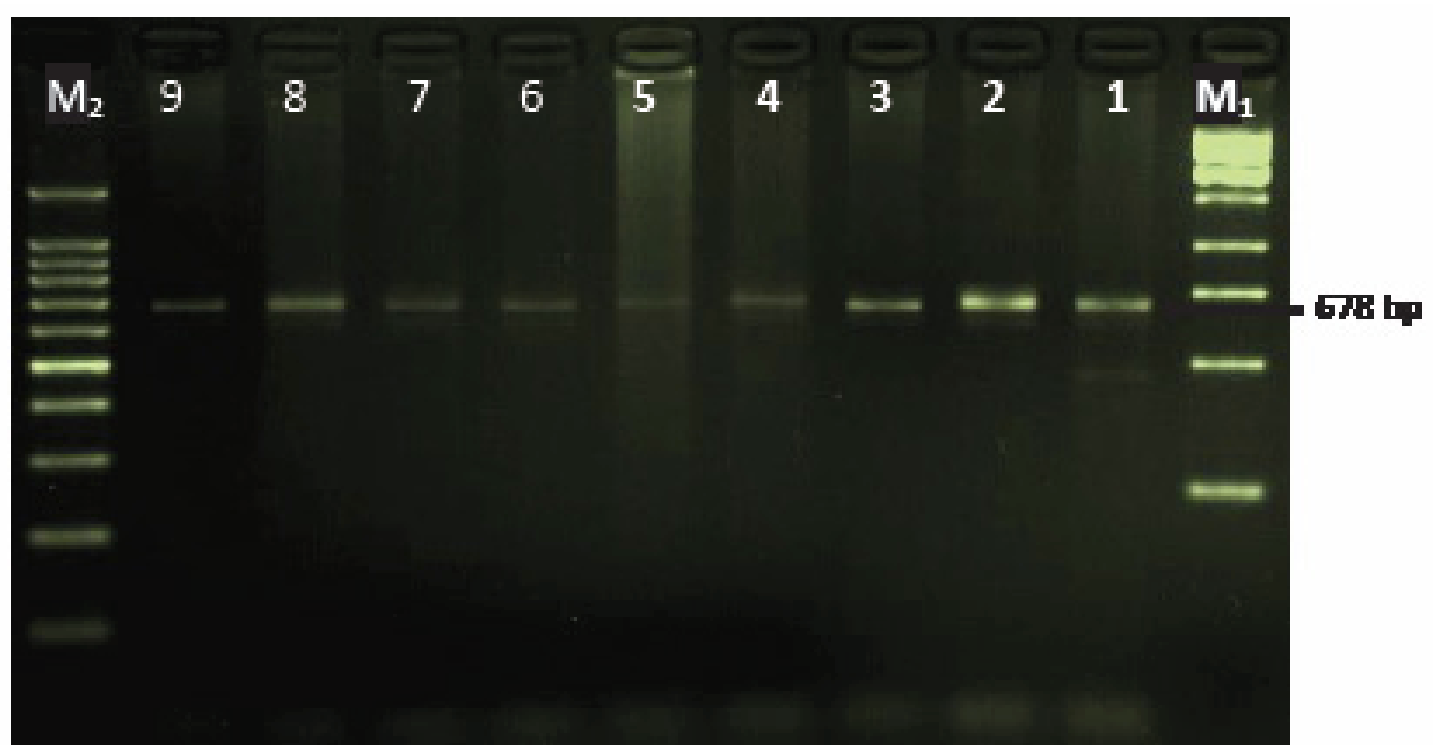

Fig. 3. Red safe-stained gel of PCR products representing amplification of PRL gene in buffalo bulls visualized on $2 \%$ agarose gel. $M_{1}$ : 250-bp ladder marker. Lanes 19- resemble 678-bp PCR products. $M_{2}$ : 100-bp ladder marker.

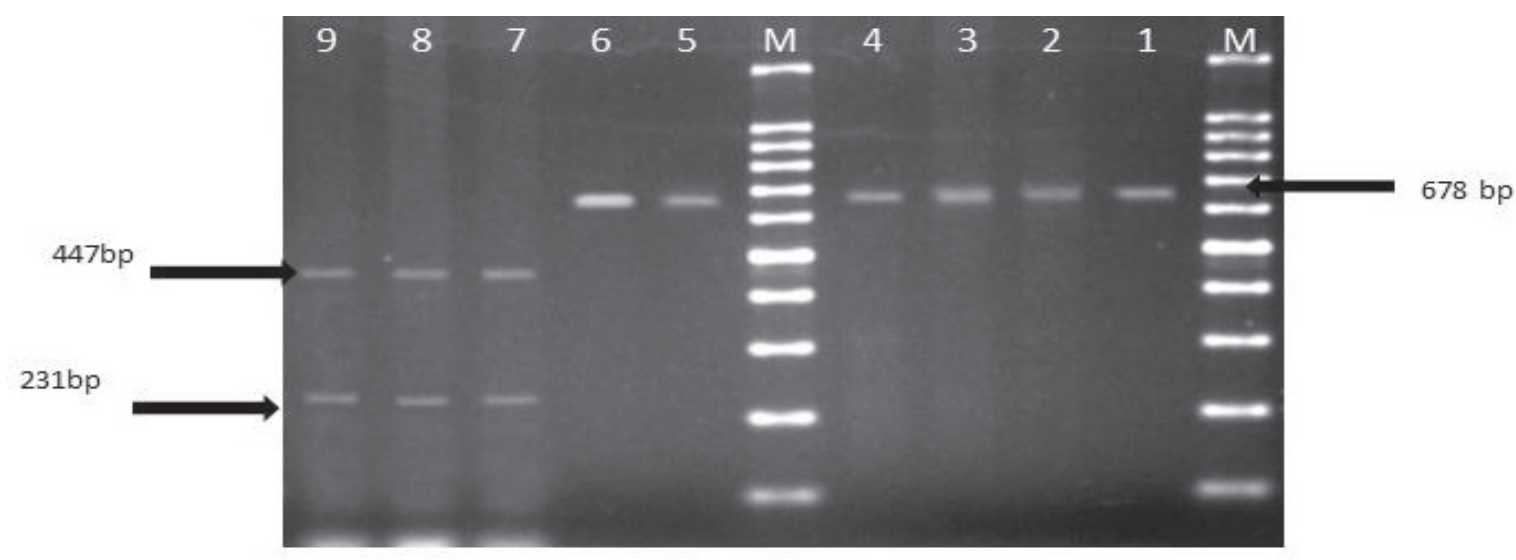

Fig. 4. Red safe-stained 2\% agarose gel of RFLP products for PRL PCR digested with XbaI enzyme. M: 100-bp ladder. Lanes 1-6 showed AA genotype of $678 \mathrm{bp}$, lane 7-9 showed BB genotype of two digested fragments at 231 and $447 \mathrm{bp}$.

TABLE 2. Frequencies of different genotypes of prolactin gene in buffalo bulls.

\begin{tabular}{lcc}
\hline Genotype & Number of bulls & Genotype frequency \\
\hline & 55 & $91.67 \%$ \\
BA & 5 & $8.33 \%$ \\
\hline
\end{tabular}


TABLE 3. Effect of genotypes of prolactin gene on characteristics of buffalo semen (Mean \pm S.E).

\begin{tabular}{lcc}
\hline Semen characteristics & AA & Genotype \\
\hline Ejaculate volume $(\mathrm{ml})$ & $2.45 \pm 0.11$ & BB \\
Individual motility \% & $75.40 \pm 1.48$ & $76.80 \pm 2.14$ \\
Live sperm \% & $81.50 \pm 1.55$ & $79.80 \pm 1.42$ \\
Chromatin damage \% & $0.85 \pm 0.37$ & $1.30 \pm 0.47$ \\
\hline
\end{tabular}

\section{Discussion}

According to our results, the body condition score has no significant effect on fresh semen characteristics of buffalo bulls. Similarly, Sarder [34] pointed that, there were no significant effects of body condition score of bulls on some semen characteristics. Meanwhile, Addass [35] reported that, there were significant effects of body condition score of bulls on sperm production potential and scrotal circumference. Also Beran et al. [36] observed significant effects of body condition score of bull on the sperm motility, sperm concentration and percentage of abnormal sperm.

Okere et al. [37] studied the relationships among body condition score, body weight, testicular traits and semen output in electroejaculate pubertal kiko goat bucks. There were low and negative correlations between body condition score and body weight and semen volume indicating that semen output is independent of body condition score and body weight. Moreover, Akpa et al. [38] observed that, body condition score of red Sokoto goat had no significant influence on sperm motility, live and dead ratio and sperm concentration but it had a significant influence on semen volume and semen PH.

In mammals especially dairy cattle, the prolactin gene has important functions like the development of mammary gland and affecting milk yield and composition [39]. PRL gene seems to be promising potential candidate gene associated with dairy performance traits and used in marker-assisted selection of dairy farm animals because it plays a crucial role in mammary gland development and in the initiation and maintenance of lactation and expression of milk protein genes [15].In the present study, genetic polymorphism was recorded in PCR product of 678 bp fragment from 5 regulatory region of prolactin gene in the studied buffalo bulls with presence of AA genotype in high frequencies while BB genotype in low frequencies, which indicates a presence of genetic variation in Egyptian buffalo bulls in that fragment of this gene.Nearly the same results were recorded previously by Li et al. [26] who concluded that, the BB genotyped cows yielded significantly higher milk yield, milk protein and milk fat than AB cows. Meanwhile, no significant effects of the AA genotype on the above traits.

Kumari et al. [39] mentioned that a silent $A \rightarrow G$ transition mutation in exon 3 of bovine prolactin gene that encodes amino acid 103 which created a polymorphic RsaI site. Also, Dybus [40] studied the associations of prolactin genes polymorphic $R s a$ I site with milk production traits in Polish Black and White cattle. He recorded genotype frequencies of 0.734 for AA, 0.257 for $\mathrm{AB}$ and 0.009 for $\mathrm{BB}$. He noticed that AA cows produce milk with higher protein content than $\mathrm{AB}$ and $\mathrm{BB}$ individuals. In addition, Boleckova, et al.[41] recorded the association of PRL RsaI polymorphisms with milk production traits in Czech Fleckvieh cattle. The genotype frequencies were 0.01 for AA, 0.22 for AG and 0.77 for GG fragment with allele frequencies of 0.12 for $A$ and 0.88 for $\mathrm{G}$ allele. Besides that, Mehmannavaz et al.[22] analyzed the PRLRsaI polymorphisms in Iranian Holstein bulls and the frequencies recorded for $A$ and $G$ alleles were 0.069 and 0.931 , respectively. The allelic substitution effect for A was significant for milk and protein yield ( $\mathrm{p}$ $<0.05$ ) where the G allele was unfavorable for milk and protein yield. Moreover, Ghasemi et al. [42] studied associations between RsaI polymorphisms of the prolactin gene and milk production traits in Montebeliard cows. They used PCR-RFLP method for identification of genotypes. They recorded genotypes frequencies of $0.81,0.15$ and 0.04 for $\mathrm{A} / \mathrm{A}, \mathrm{A} / \mathrm{B}$ and $\mathrm{B} / \mathrm{B}$, respectively with frequency of 0.89 for $A$ allele. The mean of their total milk yield was significantly higher in the AA genotype group compared to other groups where the mean of total milk production was 5805 litter for AA genotype, 4800 litter for AB genotype and 4835 litter for BB genotype. Wojdak-Maksymiec et al. [43] showed that three genotypes; AA (18.46\%), BB (2.01\%) and $\mathrm{AB}(79.53 \%)$ were shown in cattle and BB genotype had low milk 
yield. Moreover, Uddin et al. [25] reported significant associations between PRL variants and milk production traits in dairy cattle.

There are different studies on prolactin gene RsaI PCR/RFLP in buffalo that recorded monomorphic pattern AA of undigested fragment without genetic variation in all the studied population of Egyptian buffalo [29], Indigenous Anatolian Water Buffalo [27] and in Buffalo Population of Khuzestan-Iran [28].

In the present work, no significant differences between the two genotypes (AA and $\mathrm{BB}$ ) and the studied semen parameters. On this respect, no previous studies were recorded in bulls.

It could be concluded that, BCS had no effect on buffalo bulls' semen quality. The presence of genetic polymorphism in prolactin XbaI locus of buffalo bulls may acts as a genetic marker using large number of animals.

Acknowledgements: This research was supported by National Research Centre, Egypt. Project No (11020101).

\section{References}

1- Rodríguez - Martínez, H. (2003) Laboratory semen assessment and prediction of fertility, Reproduction in Domestic Animals, 38 (4), 312-318.

2- Saacke, R. (2008) Sperm morphology: Its relevance to compensable and uncompensable traits in semen, Theriogenology, 70 (3), 473-478.

3- Brito, L. F., Barth, A. D., Bilodeau-Goeseels, S., Panich, P. L. and Kastelic, J. P. (2003) Comparison of methods to evaluate the plasmalemma of bovine sperm and their relationship with in vitro fertilization rate, Theriogenology, 60 (8), 1539-1551.

4-Mahmoud, K. G. M., El-Sisy, G. A., Mohamed, A. A., El-sokary, A. A. E. and Nawito, M. (2016) Comparison of semen freezability and in-vivo fertility of Egyptian and Egyptian- Italian crossbred buffalo bulls, Global Veterinaria, 16 (5), 472-475.

5- Roca, J., Vázquez, J., Gil, M., Cuello, C., Parrilla, I. and Martinez, E. (2006) Challenges in pig artificial insemination, Reproduction in Domestic Animals, 41 (s2), 43-53.

6- Abdel Dayem, A.M.H., Mahmoud, K.Gh.M., Nawito, M.F., Ayoub, M.M. andSamah F. Darwish (2009) Genotyping of Kappa Casein gene in Egyptian buffalo bulls. Livest. Sci.,122, 286-289.
7- Hasanain, M.H. , Mahmoud, K.Gh. M., EL-Menoufy, A.A., Sakr, A.M., Ahmed,Y.F. and Othman O. E. (2016)Semen characteristics and genotyping of pituitary-specific transcription factor gene in buffalo using PCR-RFLP. Egyptian Journal of Veterinary Science, 47 (1), 13-26.

8- Spanò, M., Bonde, J. P., Hjøllund, H. I., Kolstad, H. A., Cordelli, E., Leter, G. andTeam, D. F. P. P. S. (2000) Sperm chromatin damage impairs human fertility, Fertility and Sterility, 73 (1), 43-50.

9- Mahmoud, K. G. M., El-Sokary, A., Abdel-Ghaffar, A., Abou El-Roos, M. andAhmed, Y. (2015) Analysis of chromatin integrity and DNA damage of buffalo spermatozoa, Iranian Journal of Veterinary Research, 16 (2), 161-166.

10-Rasul, Z., Ahmad, N. and Anzar, M. (2001) Changes in motion characteristics, plasma membrane integrity, and acrosome morphology during cryopreservation of buffalo spermatozoa, Journal of Andrology, 22 (2), 278-283.

11- Ladani, D., Pipalia, D., Brahmkshtri, B., Rank, D., Joshi, C., Vataliya, P. andSolanki, J. (2003) PCRRFLP polymorphism at prolactin locus in buffaloes, Buffalo Journal, 19 (2), 237-242.

12- Le Provost, F., Leroux, C., Martin, P., Gaye, P. and Djiane, J. (1994) Prolactin gene expression in ovine and caprine mammary gland, Neuroendocrinology, 60 (3), 305-313.

13- Sinha, Y. (1995) Structural variants of prolactin: occurrence and physiological significance, Endocrine Reviews, 16 (3), 354-369.

14-Barendse, W., Vaiman, D., Kemp, S., Sugimoto, Y., Armitage, S., Williams, J.,Sun,H., Eggen, A., Agaba, M. and Aleyasin, S. (1997) A mediumdensity genetic linkage map of the bovine genome, Mammalian Genome, 8 (1), 21-28.

15- Lazebnaya, I., Sulimova, G., Lazebny, O. and Khatami, S. (2013). Use of the Bovine Prolactin Gene (bPRL) for Estimating Genetic Variation and Milk Production in Aboriginal Russian Breeds of Bos taurus L, Intech, 35-52

16- Arias, J. A., Keehan, M., Fisher, P., Coppieters, W. and Spelman, R. (2009) A high density linkage map of the bovine genome, BMC genetics, 10 (1), 18.

17-Camper, S.A., Luck, D.N., Yao, Y., Woychik, R.P., Goodwin, R.G., Lyons JR, R.H. and Rottman, F.M. (1984) Characterization of the bovine prolactin gene, $D N A, 3$ (3), 237-249. 
18-Wallis, M. (1974) The primary structure of bovine prolactin, FEBS letters, 44 (2), 205-208.

19-Bennewitz, J., Reinsch, N., Guiard, V., Fritz, S., Thomsen, H., Looft, C., Kühn, C., Schwerin, M., Weimann, C. and Erhardt, G. (2004) Multiple quantitative trait loci mapping with cofactors and application of alternative variants of the false discovery rate in an enlarged granddaughter design, Genetics, 168 (2), 1019-1027.

20- Brym, P., Kamiński, S. and Wójcik, E. (2004) Nucleotide sequence polymorphism within exon 4 of the bovine prolactin gene and its associations with milk performance traits, Journal of Applied Genetics, 46 (2), 179-185.

21-Alipanah, M., Kalashnikova, L. and Rodionov, G. (2007) Association of prolactin gene variants with milk production traits in Russian Red Pied cattle, Iranian Journal of Biotechnology, 5 (3), 158-161.

22- Mehmannavaz, Y., Amirinia, C., Bonyadi, M. and Torshizi, R. V. (2009) Effects of bovine prolactin gene polymorphism within exon 4 on milk related traits and genetic trends in Iranian Holstein bulls, African Journal of Biotechnology, 8 (19) 4797 4801.

23-Dybus, A. (2002) Associations of growth hormone (GH) and prolactin (PRL) genes polymorphisms with milk production traits in Polish Black-andWhite cattle. Anim. Sci. Pap. Rep.,20(4) 203-212.

24-Khatami, S., Lazebny, O., Maksimenko, V. and Sulimova, G. (2005) Association of DNA polymorphisms of the growth hormone and prolactin genes with milk productivity in Yaroslavl and Black-and-White cattle, Russian Journal of Genetics, 41 (2), 167-173.

25-Uddin, R. M., Babar, M. E., Nadeem, A., Hussain, T., Ahmad, S., Munir, S.,Mehboob, R. and Ahmad, F. J. (2013) Genetic analysis of prolactin gene in Pakistani cattle, Molecular Biology Reports, 40 (10), 5685-5689.

26- Li, J., Wang, A., Chen, P., Li, H., Zhang, C. and Du, L. (2006) Relationship between the polymorphisms of 5) regulation region of prolactin gene and milk traits in Chinese Holstein dairy cows, AsianAustralasian Journal of Animal Sciences, 19 (4), 459-462.

27-Kaplan, S. and Boztepe, S. (2010) The Determination of Prolactin Gene Polymorphism Using PCR-RFLP Method within Indigenous Anatolian Water Buffalo and Brown Swiss. $2^{\text {nd }}$ International Symposium on Sustainable Development, Sciencebook, 168-173.
28-Tabar, Y. S., Fayazi, J., Roshanfekr, H., Mirzadeh, K. and Sadr, A. (2010) Investigation of prolactin polymorphism in buffalo population of KhuzestanIran by PCR-RFLP, Journal of Animal and Veterinary Advances, 9 (2), 284-286.

29- Othman, O. E., Zayed, F. A., El Gawead, A. A. and El-Rahman, M. R. (2011) Genetic polymorphism of three genes associated with milk trait in Egyptian buffalo, Journal of Genetic Engineering and Biotechnology, 9 (2), 97-102.

30- Alapati, A., Kapa, S. R., Jeepalyam, S., Rangappa, S. M. P. and Yemireddy, K. R. (2010) Development of the body condition score system in Murrah buffaloes: validation through ultrasonic assessment of body fat reserves. Journal of Veterinary Science, $11(1), 1-8$

31- Martins, C. F., Báo, S. N., Dode, M., Correa, G. A. and Rumpf, R. (2007) Effects of freeze-drying on cytology, ultrastructure, DNA fragmentation, and fertilizing ability of bovine sperm, Theriogenology, 67 (8), 1307-1315.

32-Weyrich, A. (2012) Preparation of genomic DNA from mammalian sperm, Current Protocols in Molecular Biology, 2(13) 11-13.

33- Mullis, K., Faloona, F., Scharf, S., Saiki, R., Horn, G. and Erlich, H. (1992) Specific enzymatic amplification of DNA in vitro: the polymerase chain reaction, Biotechnology Series, 17.

34-Sarder, M. J. U. (2008) Effects of age, body weight, body condition and scrotal circumference on sperm abnormalities of bulls used for artificial insemination (AI) programme in Bangladesh, University Journal of Zoology, Rajshahi University, 27 73-78.

35- Addass, P. (2002) Effect of age and body condition score on sperm production potential among some indegenous bull cattle in Mubi Adamawa State, Nigeria, Age, 1,1-5.

36-Beran, J., Stádník, L., Ducháček, J., Toušová, R., Louda, F. and Štolc, L. (2014) Effect of bulls» breed, age and body condition score on quantitative and qualitative traits of their semen, Acta Universitatis Agriculturae et Silviculturae Mendelianae Brunensis, 59 (6), 37-44.

37-Okere, C., Bradley, P., Bridges, E., Bolden-Tiller, O., Ford, D. and Paden, A.(2011) Relationships among body conformation, testicular Traits and semen output in electro-ejaculate Pubertal kiko goat bucks, ARPN J. of Agric. and Bio. Sci, 6 43-48. 
38- Akpa, G., Ambali, A. and Suleiman, I. (2013) Body conformation, testicular and semen characteristics as influenced by age, hair type and body condition of Red Sokoto goat, New York Science Journal, 6 (7), 44-58.

39- Kumari, A. R., Singh, K., Soni, K., Patel, R., Chauhan, J. and RAO, K. S. (2008) Genotyping of the polymorphism within exon 3 of prolactin gene in various dairy breeds by PCR RFLP (Brief report), Archiv Tierzucht/Archives Animal Breeding, 51 (3), 298-299.

40- Dybus, A., Grzesiak, W., Kamieniecki, H., Szatkowska, I., Sobek, Z., Błaszczyk, P., Czerniawska-Piątkowska, E., Zych, S. and Muszyńska, M. (2005) Association of genetic variants of bovine prolactin with milk production traits of Black-and-White and Jersey cattle, Arch .Tierz., 48, 149-156.
41-Boleckova, J., Matejickova, J., Stipkova, M., Kyselova, J. and Barton, L. (2012) The association of five polymorphisms with milk production traits in Czech Fleckvieh cattle. Czech. J. Anim. Sci., 57 (2), 45-53.

42-Ghasemi, N., Zadehrahmani, M. Rahimi, G. and Hafezian, S. H. (2009) Associations between prolactin gene polymorphism and milk production in montebeliard cows. International Journal of Genetics and Molecular Biology, 1 (3), 048-051.

43-Wojdak-Maksymiec, K., Kmic, M., Strzalaka, J. and Judyma, U. D. (2008) Prolactin gene polymorphism and somatic cell count in dairy cattle. Journal of Animal and Veterinary Advances, 7 (1), 35-40.

(Received 8/4/2017; accepted 6 / 8/ 2017)

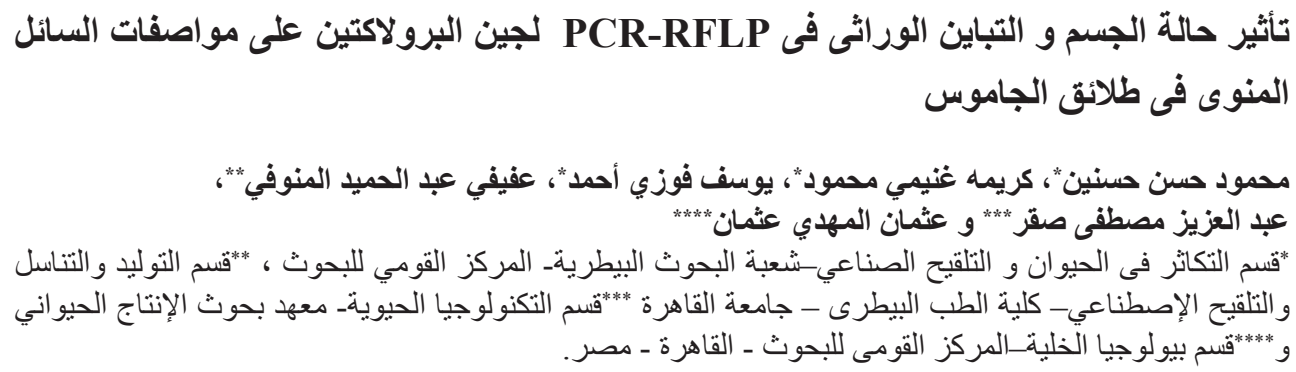

تهدف هذه الدراسة الى تقييم نأثثير حالة الجسم على مواصفات السائل المنوى فى الجاموس و تحديد التباين

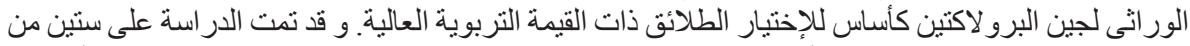

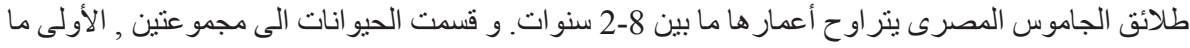

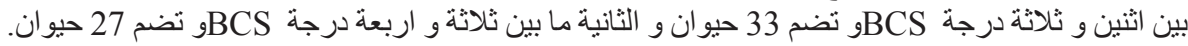

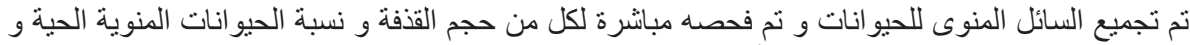

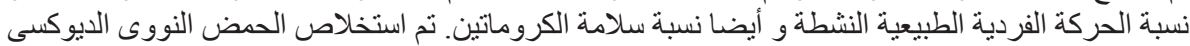

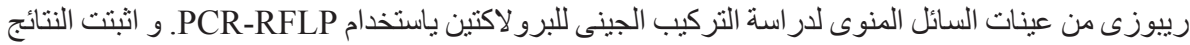

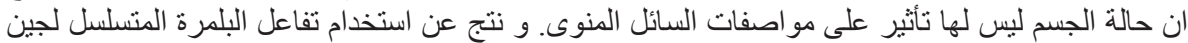

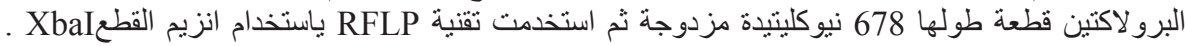

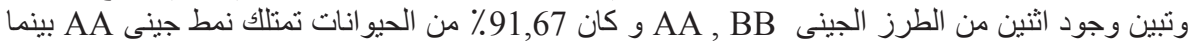

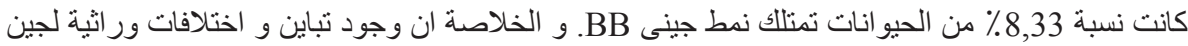

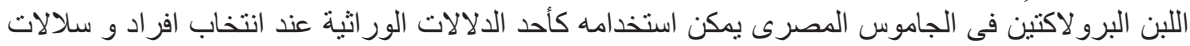
جيدة للتربية. الكلمات الدالة :الجاموس- السائل المنوي -تفاعل البلمرة المتسلسل ، RFLP ـالبرو لاكتين . 